\title{
Serum zinc and copper concentrations in relation to spontaneous abortion in cows: implications for human fetal loss
}

\author{
T. W. Graham ${ }^{1,3}$, M. C. Thurmond ${ }^{1}$, M. E. Gershwin ${ }^{2}$, J. P. Picanso ${ }^{1}$, \\ J. S. Garvey ${ }^{4}$ and C. L. Keen ${ }^{2,3}$ \\ ${ }^{1}$ Departments of Medicine and Epidemiology, School of Veterinary Medicine; ${ }^{2}$ Department of Internal \\ Medicine, School of Medicine; ${ }^{3}$ Department of Nutrition, University of California, Davis, CA 95616, \\ USA; and ${ }^{4}$ Cellular, Molecular and Developmental Neurobiology, Division of Biology 156-29, California \\ Institute of Technology, Pasadena, CA 91125, USA
}

\begin{abstract}
The purpose of this study was to investigate the effect of the status of dietary zinc and serum zinc and copper concentrations on the risk of fetal loss in 570 cows. Three herds received no supplements (herds $1,3,4$ ), while cows in herd 2 received supplements of either $7 \mathrm{~g}$ zinc week ${ }^{-1}(n=118)$, as zinc methionine, or a control diet containing methionine $(n=128)$. Serum zinc, copper and metallothionein concentrations were determined once a month throughout gestation. Logistic regression and survival analysis were used to examine for associations between risk of fetal loss and serum zinc, copper, copper:zinc, or metallothionein concentrations, supplement level, and maternal age at conception. The risk of fetal loss increased when both serum zinc decreased and copper concentrations increased $(P<0.0001$; relative risk $=10.28,95 \%$ confidence intervals $=4.69,22.5)$. The attributable risk, for a decline in the zinc concentration by $10 \mu \mathrm{mol} \mathrm{l}^{-1}$ and an increase in the copper concentration by $5 \mathrm{mmol} \mathrm{l}^{-1}$ was $90.27 \%$. Methionine-supplemented cows had a higher risk of fetal loss compared with zinc-methionine-supplemented cows (one-tailed $P=0.0375$; relative risk $=2.98$ ). Cows in herds 1,3 and 4 had a higher risk for abortion than did zinc-methionine-supplemented cows in herd 2 (relative risk $=26.27,95 \%$ confidence intervals $=2.31,299.38$; relative risk $=40.87,95 \%$ confidence intervals $=3.50,458.43$; relative risk $=41.53,95 \%$ confidence intervals $=3.77,457.02$, respectively). Our results suggest that inflammation and zinc nutriture may play an important role in fetal loss in dairy cows.
\end{abstract}

\section{Introduction}

Patterns of fetal loss in dairy cows and women are similar: both experience spontaneous abortion at comparable frequencies ( $10 \%$ versus $12-15 \%$, respectively; Kline et al, 1989; Thurmond et al., 1990a, b; Thurmond and Picanso, 1990) and the duration of gestation for cattle (284 days) and women (270 days) is comparable (Anderson, 1991). Spontaneous bovine fetal loss is defined as fetal death between gestational day 42 (clinical recognition of pregnancy per rectum) and gestational day 260 (Thurmond and Picanso, 1990). Spontaneous human fetal loss is defined as fetal death before the 28th week of pregnancy (gestational day 196). It should be noted that many human epidemiological studies delimit the period at risk for fetal loss to the period after clinical recognition of pregnancy (5-7 weeks after the last menstrual period) until the 28th week (Kline et al., 1989). In cattle, the distribution and period of greatest risk for fetal loss, after clinically recognized pregnancy, is similar (peak incidence at 6-18 weeks; Thurmond et al, 1990a, b; Thurmond and Picanso, 1990) to that described for women (peak incidence at 7-19 weeks; Wilcox et al., 1988; Kline et al., 1989; Hertz-Picciotto et al., 1989; Goldhaber and Fireman, 1991).

Karyotypically abnormal fetuses account for approximately a third of spontaneously aborted fetuses in women $(22-61 \%)$, but the cause of these chromosomal aberrations is rarely established (Kline et al., 1989). In the remaining two-thirds of karyotypically normal aborted human fetuses, fever and infection are significant risk factors for fetal loss (Kline et al., 1985). Similarly, many infectious agents have been associated with approximately $30 \%$ of bovine abortions (Anderson et al., 1991; Kirkbride, 1992a, b, 1993; Knudtson and Kirkbride, 1992), but most cases lack an aetiological diagnosis. However, the reported fetal age is consistently 2-3 months older than the period of greatest risk for abortion (Thurmond and Picanso, 1990; Anderson et al., 1991; Kirkbride, 1992a, b, 1993; Knudtson and Kirkbride, 1992); these bovine fetuses may not be representative of fetuses lost during the peak incidence of abortion. As in the case of early fetal loss in women, factors leading to chromosomal aberrations in cattle may be important causes of abortion in cattle. 
Primary or secondary zinc ( $\mathrm{Zn}$ ) deficiency has been suggested to be a causal factor in fetal loss, malformations, premature and postmature birth, and small-for-gestational-age infants in women (Hambidge et al., 1975; Jameson, 1976; Lazebnik et al., 1988; Cherry et al., 1989; Hinks et al., 1989; Keen and Hurley, 1989; Apgar, 1992; Keen et al., 1993a, b), nonhuman primates (Keen et al., 1993b), rodents (Keen and Hurley, 1989; Apgar, 1992) and sheep (Egan, 1972; Masters and Fels, 1980; Masters and Moir, 1983; Apgar, 1992). In addition, periconceptional $\mathrm{Zn}$ deficiency has been associated with abnormalities in early embryonic growth in rats and mice (Hurley and Shrader, 1975; Peters et al., 1991) and karyotypic changes in severely Zn-deficient rats (Bell et al., 1975). Zn supplementation has been suggested to reduce pregnancy complications and improve fetal growth and pregnancy outcome in women (Jameson, 1976; McMichael et al., 1982; Cherry et al., 1989; Simmer et al., 1990) and typically managed sheep (Egan, 1972; Masters and Fels, 1980; Masters and Moir, 1983). Low concentrations of $\mathrm{Zn}$ (serum and/or leukocyte $\mathrm{Zn}$ concentrations) in women have been associated with a higher incidence of fetal loss and abnormalities compared with controls (Hambidge et al., 1975; Jameson, 1976; Meadows et al., 1981; Breskin et al., 1983; Mukherjee et al., 1984; Wells et al., 1987; Higashi et al., 1988; Hinks et al., 1989; Cherry et al., 1989; Keen and Hurley, 1989; Apgar, 1992; Keen et al., 1993b), although others have reported that the $\mathrm{Zn}$ status may not affect pregnancy outcome (Hunt et al., 1984; Ghosh et al., 1985; Hunt et al., 1985; Austen et al., 1989; Mahomed et al., 1989; Apgar, 1992).

The purpose of the present study was to examine relationships between fetal loss and monthly serum concentrations of $\mathrm{Zn}, \mathrm{Cu}$ and metallothionein supplementation in 570 commercial dairy cows, while adjusting for herd of origin and age at conception.

\section{Materials and Methods}

\section{Animals}

To increase the power of our test and to decrease the chance that an unrepresentative herd was selected, we examined the relationship between abortion and maternal and environmental factors in four commercial herds of Holstein dairy cows. The infrequency of fetal loss (10\%; Thurmond and Picanso, 1990) means that many pregnancies must be analysed to detect differences between presumed causally related factors and fetal loss in aborting and nonaborting cows. If a factor (i.e. increasing maternal age, higher serum copper concentration, lower serum zinc concentration) has the same magnitude and direction of change in aborting compared with nonaborting cows in several herds, then the likelihood that those observed changes are causally associated with abortion is increased (Kline et al., 1989). The Animal Use and Care Administrative Advisory Committee approved all procedures and methods of animal handling. Demographical information for all herds included age, number of previously completed pregnancies (parity), date of supplementation, date of conception, date of abortion, and date of blood collection. After generation and verification of all laboratory data, demographical information, treatment group
Table 1. Demographic information, rates of abortion and times to abortion in Holstein dairy cows

\begin{tabular}{|c|c|c|}
\hline $\begin{array}{l}\text { Herd number } \\
\text { (Number milked) } \\
\text { [Number sampled] }\end{array}$ & $\begin{array}{l}\text { Number aborted/ } \\
\text { number not aborted }\end{array}$ & $\begin{array}{l}\text { Days in } \\
\text { gestation at } \\
\text { abortion }\end{array}$ \\
\hline $\begin{array}{l}1 \\
(757) \\
{[110]}\end{array}$ & $\begin{array}{l}9 / 101 \\
(8.2 \%)^{a}\end{array}$ & $\begin{array}{l}122^{\mathrm{b}} \\
(145)^{\mathrm{c}} \\
77-150^{\mathrm{d}}\end{array}$ \\
\hline $\begin{array}{l}3 \\
(1188) \\
{[112]}\end{array}$ & $\begin{array}{l}13 / 99 \\
(11.6 \%)\end{array}$ & $\begin{array}{l}135 \\
(125) \\
52-236\end{array}$ \\
\hline $\begin{array}{l}4 \\
(631) \\
{[102]}\end{array}$ & $\begin{array}{l}14 / 88 \\
(13.7 \%)\end{array}$ & $\begin{array}{l}117 \\
(116.5) \\
71-183\end{array}$ \\
\hline $\begin{array}{l}2 \\
\text { Zn methionine } \\
(97) \\
{[118]}\end{array}$ & $\begin{array}{l}2 / 116 \\
(1.7 \%)\end{array}$ & $\begin{array}{c}113 \\
(113) \\
107-119\end{array}$ \\
\hline $\begin{array}{l}2 \\
\text { Methionine } \\
(104) \\
{[128]}\end{array}$ & $\begin{array}{l}5 / 123 \\
(3.9 \%)\end{array}$ & $\begin{array}{c}89 \\
(84) \\
71-116\end{array}$ \\
\hline $\begin{array}{l}1,3,4 \\
\text { Untreated } \\
(2576) \\
{[324]}\end{array}$ & $\begin{array}{l}36 / 288 \\
(11.1 \%)\end{array}$ & $\begin{array}{l}125 \\
(122) \\
52-236\end{array}$ \\
\hline
\end{tabular}

aPercentage of cows that aborted [aborted/(nonaborted + aborted $) \times 100]$.

${ }^{b}$ Mean number of days in gestation at abortion.

${ }^{\mathrm{c}}$ Median number of days in gestation at abortion.

${ }^{\mathrm{d}}$ Minimum and maximum.

and data for identification of pregnancy outcome were collated for each dam. Demographical information for each herd included the total number of adult cows in the herd, the number of cows in the study that aborted, the number of cows in the study that did not abort, the percentage of cows in the study that aborted, the mean number of days to abortion, the median number of days to abortion, and the minimum and maximum number of days to abortion (Table 1 ).

Three dairy herds (herds 1, 3 and 4) were monitored for risk of fetal loss; demographical, health, vaccination and management information, and methods used to assess prospectively the effects of infectious agents on abortion in these cows have been reported (Thurmond et al., 1990b). Briefly, pregnant cows were enrolled at diagnosis of pregnancy and blood was collected monthly until death, removal from the herd (2-3 months after abortion) or until cessation of lactation. Serum was removed from the red cell mass and stored at $-70^{\circ} \mathrm{C}$ in plastic microfuge tubes identified by accession number. Cows in herds I, 3 and 4 were considered to be typically fed controls and were used for comparison with the $\mathrm{Zn}$-supplemented cows in herd 2.

Cows in herd 2 were administered vaccines for the common abortifacient agents Brucella bovis, infectious bovine rhinotracheitis virus (IBRV), bovine virus diarrhoea virus (BVDV), bovine parainfluenza-3 and antigens to five Leptospira serovars 
between 4 and 6 months of age. This vaccination protocol was similar to that in herds 1,3 and 4 . With the exception of the vaccine for brucellosis; this was repeated at 14-16 months of age and after each full gestation. Cows in herd 2 had a rolling average milk production of $10634.5 \mathrm{~kg}$ milk and $367 \mathrm{~kg}$ fat per cow year ${ }^{-1}$. The average time from calving to conception was 121 days and the intercalving interval was 13.52 months.

\section{Dietary supplementation}

A prospective double-masked $\mathrm{Zn}$ supplementation trial was conducted on herd 2 between 3 June 1990 and 30 June 1991. A random numbers generator (Statgraphics ${ }^{\mathfrak{B}}$, STSC Inc., Rockville, MD) was used to assign cows in herd 2 to either a Zn-methionine-supplemented or a methionine-supplemented group. Cows were given a colour-coded paste supplement once a week $(n=118)$, which contained a hydrogenated vegetable oil carrier with either $\mathrm{Zn}$ methionine $\left(7 \mathrm{~g} \mathrm{Zn} \mathrm{week}^{-1}\right.$; Zinpro Corporation, Bloomington, $\mathrm{MN}$ ) or an equivalent amount of methionine and $\mathrm{NaSO}_{4}$ (control cows $n=128$ ). The amount of $\mathrm{Zn}$ supplementation was intended to double the National Research Council's (1988) weekly dietary intake of $\mathrm{Zn}$ at the time that a cow would become pregnant (maximum dietary dry matter intake of $3.5 \%$ for a cow's bodyweight $(\mathrm{BW}) \times 750 \mathrm{~kg}$

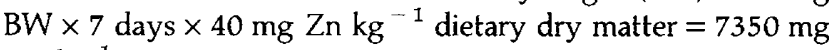
week $^{-1}$ ).

Blood was collected once a month in plastic syringes with ammonium heparin (Sarstedt Laboratories Inc., Newton, NC) and centrifuged at $4^{\circ} \mathrm{C}$ and $1200 \mathrm{~g}$ for $20 \mathrm{~min}$. The plasma was removed and allocated separately into plastic microfuge tubes previously identified with an accession number to maintain a masked trial. Plasma was frozen in liquid nitrogen, returned to the laboratory and stored at $-20^{\circ} \mathrm{C}$ prior to determination of $\mathrm{Zn}$ and $\mathrm{Cu}$, or at $-70^{\circ} \mathrm{C}$ before determination of metallothionein. Reproductive examinations were performed per rectum twice a month, and pregnancy was confirmed at approximately gestational day 40, again at day 150 and at cessation of lactation (gestational day 220). Date of abortion was estimated as described by Thurmond and Picanso (1990). Period of risk for abortion was defined as gestational days 42-260 (Thurmond and Picanso, 1990).

\section{Feed and supplement analysis}

Feed concentrations of $\mathrm{Cu}, \mathrm{Fe}, \mathrm{Mn}$ and $\mathrm{Zn}$ were determined following the methods of the Association of Official Analytical Chemists (1980) (Ingman Laboratories, Minneapolis, MN 55415). Dietary analysis of feedstuffs was completed for herd 2 only (range of monthly feed samples: $27-54 \mathrm{mg} \mathrm{Zn;} \mathrm{13-19} \mathrm{mg}$

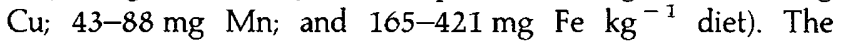
concentration of metals in the supplements was determined by inductively coupled plasmapheresis ( $\mathrm{Zn}$ methionine supplement, $7.33 \mathrm{~g} \mathrm{Zn} \mathrm{per} \mathrm{cow} \mathrm{week}{ }^{-1}$; methionine supplement, $0.001 \mathrm{~g} \mathrm{Zn} \mathrm{per} \mathrm{cow} \mathrm{week}^{-1}$ ) (California Veterinary Diagnostic Laboratory System, Davis, CA). Chemical analysis of the diet in herds 1, 3 and 4 was not available. However, estimated intakes of $\mathrm{Zn}, \mathrm{Cu}, \mathrm{Mn}$ and $\mathrm{Fe}$, based on analysis of individual dietary components, were as follows: $60-80 \mathrm{mg} \mathrm{Zn}$; $15-20 \mathrm{mg} \mathrm{Cu}$;
60-80 mg Mn; and 300-400 $\mathrm{mg} \mathrm{Fe} \mathrm{kg}^{-1}$ diet (Dairyman's Creamery Cooperative Association, Tulare, CA).

\section{Determination of trace elements}

$\mathrm{Zn}$ and $\mathrm{Cu}$ concentrations and the $\mathrm{Cu}: \mathrm{Zn}$ ratio were determined in $0.4-1 \mathrm{ml}$ aliquots of serum or plasma. We have previously shown that bovine $\mathrm{Zn}$ or $\mathrm{Cu}$ concentrations are similar when either plasma or serum $\mathrm{Zn}$ and $\mathrm{Cu}$ concentrations are determined; both plasma and serum samples are therefore termed serum (Keen and Feldman, 1987). Samples were wet ashed with nitric acid, as described by Clegg et al. (1981). One blank was analysed for every ten samples and two external controls were analysed with every 25 samples. Each sample was assayed at least twice, and results of external controls were used to calculate intra-assay and interassay cofficients of variation.

\section{Determination of metallothionein}

Serum metallothionein concentrations were determined by the methods of Garvey (1991), using rabbit anti-rat metallothionein (RJ-24) (J. S. Garvey), as reported by Keen et al. (1993b). Crossreaction with bovine metallothionein isoforms has been documented (Winge et al., 1986) and verified by western blot.

\section{Statistical analyses}

Preliminary descriptive data provided the mean, SEM and the range of the serum $\mathrm{Zn}, \mathrm{Cu}$ and metallothionein concentrations, and the $\mathrm{Cu}: \mathrm{Zn}$ ratio. Plots of $\mathrm{Zn}, \mathrm{Cu}$ and metallothionein concentrations for each cow throughout gestation were generated (Sigmaplot ${ }^{\mathbb{R}}$, Jandel Scientific, Corte Madera, CA). Differences between aborting and nonaborting cows for each metabolite were determined by Student's $t$ test (BMDP 3D; Sookne and Forsythe, 1990). Analysis of variance was used to examine for differences in the serum concentrations of $\mathrm{Zn}, \mathrm{Cu}$ and metallothionein and the $\mathrm{Cu} Z \mathrm{Zn}$ ratio (BMDP 7D; Dixon et al., 1990), as a means of screening for potentially confounding or explanatory variables. Differences noted between herds or treatment groups indicated possible effect modification or confounding to be considered in logistic and survival analysis models.

Logistic regression was used to obtain one estimate for risk of abortion based on herd of origin, supplementation status, age at conception, mean concentrations of $\mathrm{Zn}, \mathrm{Cu}$ and metallothionein, and the $\mathrm{Cu} Z \mathrm{Zn}$ ratio (BMDP LR; Engelman, 1990). Abortion was coded as 0 and nonabortion as 1 . Positively directed coefficients in the final model were interpreted as having a lower probability of abortion than negatively directed coefficients. The final model had the general form: abortion $=$ constant + supplement level + age at conception + time of sample collection $+\mathrm{Zn}+\mathrm{Cu}+$ metallothionein + Cu: $\mathrm{Zn}$. Five herd and treatment categories were created for use in logistic regression to form a single categorical variable: supplement level. Supplement level was classified as Zn-supplemented cows in herd 2 (presumed reference level), methionine-supplemented cows in herd 2, and 
nonsupplemented cows (in herds 1, 3 or 4). Supplement level was included as a partial design variable (Engelman, 1990), and was forced into the model with the presumption that it was a confounding or explanatory variable. Age at conception was also forced into the model as an interval-scaled continuous variable that was thought to be a proxy measure for gravidity and parity, which are known risk factors for abortion (Thurmond et al., 1990a). Time of sample collection was divided into intervals of 30 days of gestation (e.g. 0-30, $31-60$ ). Adjusted risk odds ratios (ROR) for aborting were estimated along with their approximate $95 \%$ confidence inter$\operatorname{val}(95 \% \mathrm{CI})$ as:

$$
R O R=e^{\alpha+\beta 1+\beta 2 \ldots \beta i} / e^{\alpha+\beta 1+\beta 2 \ldots \beta i}=e^{\beta X_{i}},
$$

and

$$
95 \% C I=e^{\beta_{3} X_{i} \pm 2\left(\operatorname{SE} \text { of } \beta_{1} X_{j}\right)},
$$

where $\beta_{j} X_{j}$ is the difference between the coefficient of interest $(x)$ and that of the reference level $(y)$.

Survival analysis was used as a second method for comparing relationships among nutritional, maternal and environmental factors and abortion. The Cox proportional hazard model (BMDP 2L; Hopkins, 1990) was used to determine the instantaneous risk of abortion (hazard) and relative risk of pregnancy failure when accounting for daily variations in $\mathrm{Zn}, \mathrm{Cu}$ and metallothionein concentrations, and the $\mathrm{Cu}: \mathrm{Zn}$ ratio. Pregnancy failure was defined as gestational day of fetal expulsion. Censoring occurred on the gestational day that a nonaborting cow was removed from the herd or the end of the risk period (260 days). The model had the general form:

$$
\lambda(t)=\lambda_{o}(t) e^{\left[\left[\beta 1 X 1+\beta 2 X 2 \ldots \beta_{1} X_{i}\right)+\beta(Z t)\right]} .
$$

The unknown baseline hazard was $\lambda_{o}(t), \beta_{i}$ and $X_{i}$ were the non-time-dependent co-variates (supplement level, as described for logistic regression, number of days that the cows had lactated before conception and age at conception), and $\beta(Z t)$ was the time-dependent function for $\mathrm{Zn}, \mathrm{Cu}$ and metallothionein concentrations and the $\mathrm{Cu}: \mathrm{Zn}$ ratio. The concentrations of $\mathrm{Zn}, \mathrm{Cu}$ and metallothionein and the $\mathrm{Cu}: \mathrm{Zn}$ ratio were included in the model as time-dependent co-variates because their values changed with the risk of abortion; a change in their values may be important predictors of pregnancy failure along with other explanatory variables (Cox and Oakes, 1984). To examine the time-dependent functions of the variables metallothionein, $\mathrm{Zn}$ and $\mathrm{Cu}$ concentration and the $\mathrm{Cu}: \mathrm{Zn}$ ratio on the risk of abortion, a univariate linear least-squares estimate was determined. For each cow, an estimate of the intercept (time $=0$ ) and slope for each metabolite was made, where the metallothionein, $\mathrm{Zn}$ and $\mathrm{Cu}$ concentrations and the $\mathrm{Cu}: \mathrm{Zn}$ ratio were dependent variables and gestational age (time) was the independent variable. A coefficient was interpreted to be positively associated with hazard for abortion when positive.

Validity of the assumptions of proportionality for non-timedependent co-variates and the log-linear nature of the model were tested as suggested by Kalbfleisch and Prentice (1980). Time-dependent strata were created so that an individual's time of entry into the model was adjusted to the day the cow was first bled (time of first recognition of pregnancy and inclusion in the trial). Use of time-dependent strata adjusts the time that a cow enters the model, preventing inclusion of cows that were enrolled in the study after a given failure time, following the recommendations of Hopkins and Hornung (1985). Relative risks (RR) for abortion were estimated along with their approximate $95 \% \mathrm{CI}$ as follows:

$$
R R=e^{\left[\left(\beta 1 X 1+\beta 2 X_{2} \ldots \beta_{i} X_{i}\right)+\beta(Z i)\right]} / e^{\left[\left(\beta 1 X_{I}+\beta 2 X_{2} \ldots \beta_{i} X_{j}\right)+\beta(Z i)\right]}=e^{\left(\beta_{i} X_{i}\right)},
$$

and

$$
95 \% \mathrm{CI}=\mathrm{e}^{\beta_{i} X_{i} \pm 2\left(\text { SE of } \beta_{i} X_{j}\right)},
$$

where $\beta_{\mathrm{j}} X_{\mathrm{j}}$ is the difference between the coefficient of interest $(x)$ and that of the reference level $(y)$. Variance for multiple coefficients (i.e. supplement level) was estimated as suggested by Kalbfleisch and Prentice (1980). Risk for fetal loss in the $\mathrm{Zn}$-methionine-supplemented and methionine-supplemented cows was a priori assumed to be lower in the group given $\mathrm{Zn}$ methionine; comparison of risk of fetal loss was therefore one-tailed $(P<0.05)$. In all other comparisons a direction of change was not assumed; comparisons were therefore twotailed $(P<0.05)$. A coefficient was considered to be significant when its $Z$ value was $>1.96$ (Kalbfleisch and Prentice, 1980). Attributable risk was estimated as: (relative risk -1 )/relative risk (Kahn and Sempos, 1989).

\section{Results}

\section{Assay variation}

There were 246 cows in herd 2 and 324 cows in herds 1,3 and 4 included for analysis (Table 1 ). Intra-assay coefficients of variation for determining serum $\mathrm{Zn}$ and $\mathrm{Cu}$ concentrations were $6.8 \%$ and $5.4 \%$, respectively. Interassay coefficients of variation were $10.3 \%$ for $\mathrm{Zn}$ and $5.7 \%$ for $\mathrm{Cu}$. Most samples (>90\%) were near or below the assay limit of detection for serum metallothionein. While duplicate samples had a coefficient of variation $<5 \%$, the intra-assay variation at these low metallothionein concentrations was $>50 \%$, and the interassay variation was $>100 \%$.

\section{Descriptive statistics}

Demographical and descriptive results for aborting and nonaborting cows for each supplement level are presented in Tables 1 and 2. Supplementation was begun before conception in all cows that aborted. Nonaborting cows in herd 3 had higher serum $\mathrm{Zn}$ concentrations $\left(14.72 \mu \mathrm{mol} \mathrm{l}{ }^{-1}\right)$ than did nonaborting cows in herds $1\left(13.56 \mu \mathrm{mol} \mathrm{l}{ }^{-1}\right), 2(13.87 \mu \mathrm{mol}$ $\left.\mathrm{I}^{-1}\right)$ and $4\left(13.98 \mu \mathrm{mol} \mathrm{I}^{-1}\right)(P<0.001)$. Nonaborting cows in herd 2 had higher serum $\mathrm{Cu}$ concentrations $\left(13.76 \mu \mathrm{mol} \mathrm{I}^{-1}\right)$ than did nonaborting cows in herds $1\left(9.31 \mu \mathrm{mol} \mathrm{l}^{-1}\right), 3$ $\left(9.05 \mu \mathrm{mol} 1^{-1}\right)$ and $4\left(9.19 \mu \mathrm{mol} \mathrm{I}^{-1}\right)(P<0.001)$. Nonaborting cows in herds $1\left(0.18 \mathrm{nmol} \mathrm{l}^{-1}\right)$ and $4\left(0.14 \mathrm{nmol} \mathrm{l}^{-1}\right)$ had lower serum metallothionein concentrations than did nonaborting cows in either herd $2\left(3.42 \mathrm{nmol} 1^{-1}\right)$ or $3\left(2.84 \mathrm{nmoll}^{-1}\right)$ $(P<0.01)$. Nonaborting cows in herd 2 had a higher serum $\mathrm{Cu} Z \mathrm{Zn}$ ratio (1.04) than did nonaborting cows in herds $1(0.73)$, $3(0.64)$ or $4(0.69)(P<0.01)$; both herds 1 and 4 had a higher serum $\mathrm{Cu}: \mathrm{Zn}$ ratio than did herd $3(P<0.05)$. Nonaborting $\mathrm{Zn}$-methionine-treated cows and methionine-treated cows had similar serum $\mathrm{Zn}\left(13.95,13.79 \mu \mathrm{mol} \mathrm{I}^{-1}\right), \mathrm{Cu} \quad(14.06$, 
$\left.13.48 \mu \mathrm{mol} \mathrm{l}^{-1}\right)$, and metallothionein $\left(2.82,3.98 \mathrm{nmol} \mathrm{l^{-1 }}\right)$ concentrations, and serum $\mathrm{Cu}: \mathrm{Zn}$ ratios $(1.06,1.02)(P>0.05)$.

For logistic regression and survival analysis models, ROR and $R R$ for abortion in a cow with a serum $\mathrm{Zn}$ concentration of $10 \mu \mathrm{mol} \mathrm{I}^{-1}$, serum $\mathrm{Cu}$ concentration of $15 \mu \mathrm{mol} \mathrm{I} \mathrm{I}^{-1}$ and a serum $\mathrm{Cu}: \mathrm{Zn}$ ratio of 15:10 were compared with a reference cow with a serum $Z n$ concentration of $20 \mu \mathrm{mol} \mathrm{I}^{-1}$, a serum $\mathrm{Cu}$ concentration of $10 \mu \mathrm{mol} \mathrm{I}^{-1}$ and a serum $\mathrm{Cu}: \mathrm{Zn}$ ratio of 10:20. $\mathrm{Zn}$ and $\mathrm{Cu}$ concentrations $<5 \mu \mathrm{mol} \mathrm{I} \mathrm{I}^{-1}$ (5 of 3155 and 8 of 3155 observations, respectively), $\mathrm{Zn}$ concentrations $>25 \mu \mathrm{mol} \mathrm{l^{-1 }}$ (28 of 3155), and $\mathrm{Cu}$ concentrations $>20 \mu \mathrm{mol} \mathrm{I}^{-1}$ (33 of 3155) were rarely observed in the 3155 serum samples in this study. Individual plots of serum $\mathrm{Zn}$ and $\mathrm{Cu}$ concentrations during gestation indicated that an increase in the serum $\mathrm{Cu}: \mathrm{Zn}$ ratio preceded expulsion of the fetus by up to 3 months for 22 of 42 abortions. Most cows displayed minor variations in serum $\mathrm{Cu}$ and $\mathrm{Zn}$ concentrations throughout gestation. However, a magnitude of change of $10 \mu \mathrm{mol} \mathrm{Zn} \mathrm{l} \mathrm{I}^{-1}$ (i.e. from 20 to $10 \mu \mathrm{mol} \mathrm{l}^{-1}$ ) and $5 \mu \mathrm{mol} \mathrm{Cu} \mathrm{l}{ }^{-1}$ (i.e. from 10 to $15 \mu \mathrm{mol} \mathrm{l}^{-1}$ ) was observed in aborting and nonaborting cows. Estimation of $R R$ and ROR was limited to these ranges.

\section{Logistic regression}

Results from logistic regression models suggested that supplement level (treatment and herd), age at conception, serum $\mathrm{Zn}$ and $\mathrm{Cu}$ concentrations, and the time interval in gestation during which a cow was bled were important predictive variables for estimating the odds of abortion (Table 3). Odds of abortion increased as maternal age at conception increased for each time interval examined (gestational days $31-60,61-90$ and 91-120). Odds of abortion decreased as serum $\mathrm{Zn}$ concentrations increased during days 31-60 of gestation $(\mathrm{ROR}=0.21 ; 95 \% \mathrm{CI}=0.05,0.96$; comparing a concentration of $10 \mu \mathrm{mol} \mathrm{l}^{-1}$ with a reference concentration of $20 \mu \mathrm{mol} \mathrm{Zn} \mathrm{l}^{-1}$ ). Odds of abortion increased as serum $\mathrm{Cu}$ concentrations increased during days $31-60$ of gestation $(\mathrm{ROR}=0.48 ; 95 \% \mathrm{CI}=0.21,1.08$; comparing a concentration of $15 \mu \mathrm{mol} \mathrm{l}^{-1}$ with a reference concentration of $10 \mu \mathrm{mol} \mathrm{Cu} \mathrm{l} \mathrm{I}^{-1}$ ) and days 61-90 (ROR $=0.44 ; 95 \%$ $\mathrm{CI}=0.19$, 1.04). Because the time interval during gestation appeared to interact with serum $\mathrm{Zn}$ and $\mathrm{Cu}$ concentrations, survival analysis was used to account for the potential interaction of gestational age with each metabolite.

\section{Survival analysis}

The co-variates supplement level, maternal age at conception, and the time-dependent co-variates $\mathrm{Zn} \times$ (time), $\mathrm{Cu} \times($ time$)$, and $(\mathrm{Cu}: \mathrm{Zn}) \times($ time $)$ contributed significantly to risk (hazard) of abortion (Table 4). The RR of fetal loss was lower in $\mathrm{Zn}$-methionine-treated cows than in methioninetreated cows (one-tailed $P=0.0375 ; \mathrm{RR}=2.98$ ). Cows in herds 1,3 and 4 had a higher risk of fetal loss than did Zn-methionine-supplemented cows in herd $2(R R=26.27,95 \%$ $\mathrm{CI}=2.31, \quad 299.38 ; \quad \mathrm{RR}=40.87, \quad 95 \% \quad \mathrm{CI}=3.50, \quad 458.43$; $\mathrm{RR}=41.53,95 \% \mathrm{CI}=3.77,457.02$, respectively). Similar to logistic regression models, at a fixed gestational time, as serum
$\mathrm{Zn}$ concentrations decreased and serum $\mathrm{Cu}$ concentrations increased, the risk of abortion increased $(R R=10.28,95 \%$ $\mathrm{CI}=4.69,22.5)$. The attributable risk, for a decline in the $\mathrm{Zn}$ concentration by $10 \mu \mathrm{mol} 1^{-1}$ and an increase in the $\mathrm{Cu}$ concentration of $5 \mu \mathrm{mol} \mathrm{l}^{-1} \mathrm{Cu}$ was $90.27 \%$.

\section{Discussion}

Zinc supplement level, maternal age at conception, serum $\mathrm{Zn}$ and $\mathrm{Cu}$ concentrations and serum $\mathrm{Cu}: \mathrm{Zn}$ ratios were associated with risk of fetal loss. Supplementation with $\mathrm{Zn}$ methionine was associated with a lower risk of fetal loss than methionine supplementation (controls). Similarly, Zn methionine supplementation was associated with a lower risk of fetal loss than that in unsupplemented herds 1, 3 and 4. Although cows in all four herds were the same breed (Holstein) and were considered to be in excellent health and have good rates of production, comparisons between Zn-methionine-supplemented cows in herd 2 and cows in herds 1,3 and 4 should be treated with caution, given differing management and environmental (including nutritional) factors among the herds. Maternal age at conception was an important risk factor of fetal loss in this study, as has been reported for women (Naylor and Warburton, 1979; James, 1983). For cows within a given herd, gestational stage and maternal age, low $\mathrm{Zn}$ and high $\mathrm{Cu}$ concentrations, and a high $\mathrm{Cu}: \mathrm{Zn}$ ratio were associated with fetal loss.

Serum metallothionein concentrations were not associated with fetal loss in the present study. While concentrations of metallothionein in erythrocytes have been reported to be low in Zn-deficient rats (Sato et al., 1984) and humans (Grider et al., 1990; Thomas et al., 1992), pregnant Zn-deficient rhesus monkeys were reported to have high plasma metallothionein concentrations (Keen et al., 1993b). The increased metallothionein concentrations in the pregnant monkeys were attributed to inflammation that was secondary to their severe chronic $\mathrm{Zn}$ deficiency. Reasons for a lack of association between $\mathrm{Zn}$ supplement status, fetal loss and serum metallothionein in this study are most likely because cows in this study were considered to have adequate concentrations of $\mathrm{Zn}$ and did not have a chronic inflammatory disease (i.e. marked Zn deficiency). Results obtained in the current study do not support the routine use of the measurement of serum concentrations of metallothionein as a diagnostic tool for $\mathrm{Zn}$ status or abortion in cattle.

An association between lower $\mathrm{Zn}$ and higher serum $\mathrm{Cu}$ concentrations and fetal loss can most probably be attributed to inflammation (Graham, 1991). Endotoxin-induced inflammation has been documented to cause bovine abortion experimentally (Giri et al., 1990, 1991). Increased risk of fetal loss has previously been associated with changes in antibody titres to gram-negative organisms (Leptospira) and common viral pathogens (IBRV and BVDV) in herds 1,3 and 4 (Thurmond et al., 1990b). Inflammation induced by microbial infection or microbial products (e.g. endotoxin) is associated with a decline in the plasma concentration of $\mathrm{Zn}$, and a rise in the serum concentration of $\mathrm{Cu}$ (Barber and Cousins, 1988; Lohuis et al., 1988a, b; Dinarello, 1989; Shuster et al., 1993). 


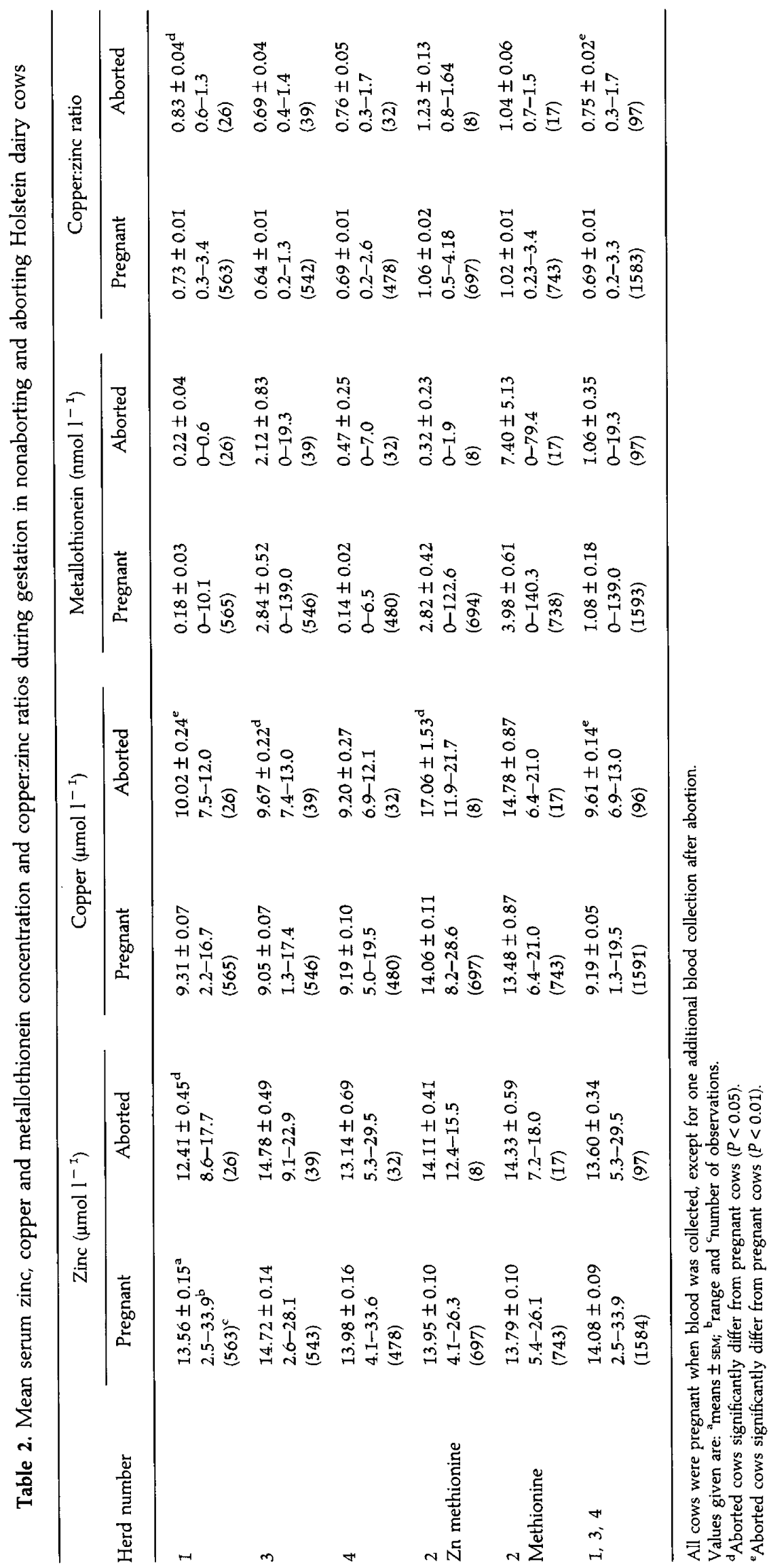


Table 3. Logistic regression models estimating the adjusted odds of a cow aborting within a given herd and age at conception [serum zinc $(\mathrm{Zn})$, copper $(\mathrm{Cu})$ and metallothionein concentrations and ratios of copper:zinc or adjusted copper:zinc ratios were included for their main effects, and gestation time (days) was divided into intervals of 30 days]

\begin{tabular}{|c|c|c|c|c|}
\hline Time interval & $\begin{array}{l}\text { Number aborted/ } \\
\text { number not aborted }\end{array}$ & $\begin{array}{c}\text { Regression coefficient } \\
\text { (SEM) }\end{array}$ & $Z$ value & $P$ value \\
\hline Days $31-60$ & $30 / 301$ & & & \\
\hline Constant & & $2.125 \quad(1.33)$ & -1.60 & 0.1034 \\
\hline \multicolumn{5}{|l|}{ Supplement level } \\
\hline D1 & & $-0.9155(0.862)$ & -1.06 & \\
\hline D2 & & $-1.379 \quad(0.828)$ & -1.67 & \\
\hline D3 & & $-1.599 \quad(0.835)$ & -1.92 & \\
\hline D4 & & $-1.777 \quad(0.824)$ & -2.16 & 0.0130 \\
\hline Age at conception & & $-0.0123(0.009)$ & -1.37 & 0.1831 \\
\hline Zinc & & $0.1547(0.0752)$ & 2.06 & 0.0285 \\
\hline Days 61-90 & $41 / 409$ & & & \\
\hline Constant & & $7.242 \quad(1.59)$ & 4.56 & $<0.00001$ \\
\hline \multicolumn{5}{|l|}{ Supplement level } \\
\hline DI & & $-1.114 \quad(0.869)$ & -1.28 & \\
\hline D2 & & $-2.179 \quad(0.954)$ & -2.28 & \\
\hline D3 & & $-2.556 \quad(0.966)$ & -2.65 & \\
\hline D4 & & $-2.786 \quad(0.934)$ & -2.98 & 0.0130 \\
\hline Age at conception & & $-0.0231(0.0077)$ & -3.00 & 0.0035 \\
\hline Copper & & $-0.1451(0.0798)$ & -1.82 & 0.0749 \\
\hline Days 91-120 & $32 / 394$ & & & \\
\hline Constant & & $7.988 \quad(1.84)$ & 4.33 & $<0.00001$ \\
\hline \multicolumn{5}{|l|}{ Supplement level } \\
\hline D1 & & $-0.8032(1.25)$ & -0.643 & \\
\hline D2 & & $-2.875 \quad(1.21)$ & -2.37 & \\
\hline D3 & & $-3.212 \quad(1.21)$ & -2.66 & \\
\hline D4 & & $3.264 \quad(1.20)$ & -2.71 & 0.0037 \\
\hline Age at conception & & $-0.021 \quad(0.0089)$ & -2.36 & 0.0219 \\
\hline Copper & & $-0.1635(0.0859)$ & -1.90 & 0.0648 \\
\hline
\end{tabular}

Gestation days $0-30,121-150,151-180,181-210,211-240$ and 241-260 were not reported because of sparse data or because estimation of their coefficients failed to converge (PCONV >0.001; LCONV >0.0001) or did not meet tolerance criteria $(0.001)$. Supplement level was coded as follows:

(1) Herd 2, Zn methionine: $\mathrm{D} 1=0, \mathrm{D} 2=0, \mathrm{D} 3=0, \mathrm{D} 4=0$.

(2) Herd 2, Methionine: D1 $=1, \mathrm{D} 2=0, \mathrm{D} 3=0, \mathrm{D} 4=0$.

(3) Herd 1, Untreated: D1 $=0, \mathrm{D} 2=1, \mathrm{D} 3=0, \mathrm{D} 4=0$.

(4) Herd 3, Untreated: $\mathrm{D} 1=0, \mathrm{D} 2=0, \mathrm{D} 3=1, \mathrm{D} 4=0$.

(5) Herd 4, Untreated: D1 $=0, \mathrm{D} 2=0, \mathrm{D} 3=0, \mathrm{D} 4=1$.

Individual plots of serum $\mathrm{Zn}$ and $\mathrm{Cu}$ concentrations during gestation suggest that a higher serum $\mathrm{Cu}$ : $\mathrm{Zn}$ ratio precedes expulsion of the fetus by up to 3 months for 22 of 42 abortions. This was supported by the results of logistic regression, in which lower serum $\mathrm{Zn}$ concentrations during the second month (31-60 days) and higher serum $\mathrm{Cu}$ concentrations during the third and fourth months of gestation (61-90 and 91-120 days) were associated with fetal loss. Results of survival analysis, which examined relationships between explanatory variables and pregnancy outcome at the time of fetal loss showed that lower $\mathrm{Zn}$ and higher serum $\mathrm{Cu}$ concentrations were highly correlated with fetal loss. Thus, lower serum $\mathrm{Zn}$ and higher serum $\mathrm{Cu}$ concentrations are associated with fetal loss before and at the time of fetal expulsion. Inflammatory or infectious changes, marked by fever, are associated with karyotypically normal fetal loss in women (Kline et al., 1985). Fever was noted to precede fetal expulsion by up to 62 days, but the odds of abortion were highest for fevers that occurred during the same month as fetal loss (Kline et al., 1985).

The present data suggest that by avoiding exposure to those factors that would cause a decrease in the plasma concentration of $\mathrm{Zn}$ of $10 \mu \mathrm{mol} \mathrm{^{-1 }}$ and an increase in the concentration of $\mathrm{Cu}$ of $5 \mu \mathrm{mol} \mathrm{I}{ }^{-1}$, approximately nine of ten abortions in cows reared under similar conditions to those in this study might be prevented (attributable risk of $90.27 \%$ ). In addition, these data suggest that approximately $90 \%$ of the abortions observed in this study are likely to be caused by inflammatory changes, rather than genetic aberrations. We suggest that future research efforts be directed at improving vaccines (e.g. endotoxin vaccines) or pharmacological intervention tactics (including nutrient intervention) that can attenuate inflammatory changes during pregnancy. 
Table 4. Cox proportional hazards models describing relationships between risk of abortion and dietary treatment, herd, age at conception, the time-dependent co-variates serum zinc, copper and metallothionein concentrations, and ratios of copper:zinc

\begin{tabular}{|c|c|c|c|c|}
\hline Variable & $\begin{array}{l}\text { Regression } \\
\text { coefficient (sE) }\end{array}$ & $Z$ value & $P$ value & $\begin{array}{c}\text { Relative risk } \\
(95 \% \text { confidence intervals })\end{array}$ \\
\hline \multicolumn{5}{|l|}{ Univariate estimate $^{a}$} \\
\hline \multicolumn{5}{|l|}{ Supplement level } \\
\hline D1 & $1.0566(0.5936)$ & 1.7802 & 0.0750 & \\
\hline D2 & $3.2686(0.6682)$ & 4.8918 & $<0.0001$ & \\
\hline D3 & $3.6906(0.6660)$ & 5.5411 & $<0.0001$ & \\
\hline D4 & $3.7264(0.6409)$ & 5.8145 & $<0.0001$ & \\
\hline (1) & & & \multicolumn{2}{|r|}{$1.0^{\mathrm{b}}$} \\
\hline$(2)$ & & & & $2.98 \quad(0.35,23.97)$ \\
\hline (3) & & & & $26.27 \quad(2.31,299.38)$ \\
\hline (4) & & & & $40.87 \quad(3.50,458.43)$ \\
\hline (5) & & & & $41.53(3.77,457.02)$ \\
\hline Age at conception & $0.0218(0.0048)$ & 4.5135 & $<0.0001$ & $1.92^{c}(1.44,2.58)$ \\
\hline Time-dependent zinc concentration & $-0.6574(0.1686)$ & -3.8981 & $<0.0001$ & $716.23^{d}(24.58,20868)$ \\
\hline Time-dependent copper concentration & $1.0065(0.2353)$ & 4.2778 & $<0.0001$ & $153.31^{e}(1.71,1612)$ \\
\hline Time-dependent copper:zinc & $-9.2763(2.8194)$ & -3.2902 & 0.0010 & $<0.00^{f}(0.00,0.026)$ \\
\hline \multicolumn{4}{|c|}{ Attributable risk for the combined time-dependent covariates $=90.27 \%$} & $10.28^{\mathrm{g}}(4.69,22.5)$ \\
\hline
\end{tabular}

${ }^{a}$ Time-dependent co-variates were based on the intercept and slope $\times$ (time) of changes in $\mathrm{Zn}, \mathrm{Cu}$ or metallothionein concentrations, and ratios of $\mathrm{Cu}: \mathrm{Zn}$ throughout gestation.

beference level.

${ }^{\circ}$ Comparing 60 months with a reference age at conception of 30 months.

${ }^{d}$ Comparing $10 \mu \mathrm{mol} \mathrm{Zn} \mathrm{^{-1 }}$ with a reference concentration of $20 \mu \mathrm{mol} \mathrm{Zn} \mathrm{I} \mathrm{I}^{-1}$ (mid-range of normal plasma $\mathrm{Zn}$ concentration).

${ }^{e}$ Comparing $15 \mu \mathrm{mol} \mathrm{Cu} \mathrm{l}{ }^{-1}$ with a reference concentration of $10 \mu \mathrm{mol} \mathrm{Cu} \mathrm{l}{ }^{-1}$ (mid-range of plasma $\mathrm{Cu}$ in this study).

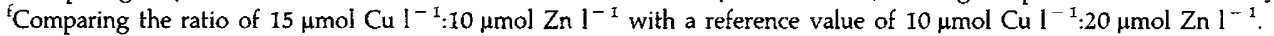

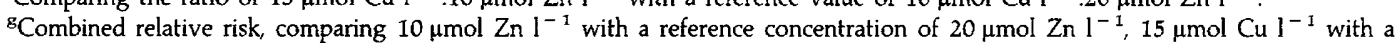

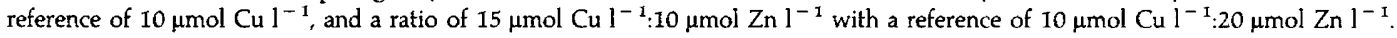
Supplement level was coded as:

(1) Herd 2, Zn methionine: D1 $=0, \mathrm{D} 2=0, \mathrm{D} 3=0, \mathrm{D} 4=0$.

(2) Herd 2, Methionine: D1 $=1, \mathrm{D} 2=0, \mathrm{D} 3=0, \mathrm{D} 4=0$.

(3) Herd 1, Untreated: D1 $=0, D 2=1, \mathrm{D} 3=0, \mathrm{D} 4=0$.

(4) Herd 3, Untreated: $\mathrm{D} 1=0, \mathrm{D} 2=0, \mathrm{D} 3=1, \mathrm{D} 4=0$.

(5) Herd 4, Untreated: $\mathrm{D} 1=0, \mathrm{D} 2=0, \mathrm{D} 3=0, \mathrm{D} 4=1$.

Differences in periods examined for risk of fetal loss (i.e. weeks $0-12$ and 12-28) can lead to bias in the interpretation of periods of greatest risk, as was previously suggested for women (Wilcox et al., 1988; Goldhaber and Fireman, 1991) and as suggested by our current data. In studies of associations between $\mathrm{Zn}$ concentration and fetal loss, patients should be enrolled before the period of greatest risk of fetal loss (i.e. $<6-8$ weeks). Similarly, the entire risk period should be monitored because of changing nutritional requirements (maternal and fetal) throughout gestation (Breskin et al., 1983; Keen et al., 1993a). In one study, in which maternal samples were collected $24 \mathrm{~h}$ after abortion or delivery, the authors concluded that the serum concentration of $\mathrm{Zn}$ was not associated with human fetal loss. However, changes in serum $\mathrm{Zn}$ concentration after expulsion are not likely to be causally related to the events that led to fetal expulsion. In contrast, our survival analysis model weighted the estimated metabolite concentration at the time of expulsion to the concentration of the samples that preceded fetal expulsion.

Serum $\mathrm{Zn}$ and $\mathrm{Cu}$ concentrations in herd 2 were equimolar and within the expected mid-range for both elements (Graham, 1991). Herds 1,3 and 4 had adequate $Z n$ concentrations, but serum $\mathrm{Cu}$ concentrations were at the low end of the expected range (7-25 $\mathrm{mol} \mathrm{I}^{-1}$; Graham, 1991). Marginal Cu status may be another factor that contributed to the higher incidence of abortion in herds 1,3 and 4 compared with herd 2. Low $\mathrm{Cu}$ concentrations have been associated with increased susceptibility to infectious agents in cattle (Stabel and Spears, 1989). Relationships between $\mathrm{Cu}$ deficiency and abortion in ruminants have been suggested before (Graham, 1991), but appear to be confounded by multiple nutrient interactions. Similarly, Zn deficiency is associated with an increased incidence of opportunistic infections and fetal loss in many species (Keen and Gershwin, 1990; Graham, 1991; Apgar, 1992). However, because measurements of $\mathrm{Zn}$ and $\mathrm{Cu}$ status are considered unreliable (Graham, 1991; Thomas et al., 1992), supplementation trials are required to assess the effects of nutrient status on risk of fetal loss fully.

To the authors' knowledge, periconceptional intervention trials using $\mathrm{Zn}$ alone have not been reported previously for cattle or women. In a recent $\mathrm{Zn}$ supplementation trial, 1 of 248 $\mathrm{Zn}$-supplemented women spontaneously aborted, compared with 5 of 249 women given a placebo (Mahomed et al., 1989). However, enrolment in the study at $<20$ weeks of gestation 
appeared to be well after conception and the period of greatest risk of fetal loss. Supplementing typically managed ewes with Zn before pregnancy results in higher fertility (Egan, 1972; Masters and Fels, 1980; Masters and Moir, 1983). In the current trial, supplementation with $\mathrm{Zn}$ methionine reduced the incidence of abortion compared with methionine-supplemented control cows, and there was a strong association between low serum $\mathrm{Zn}$ concentrations and risk of abortion. It is apparent that $\mathrm{Zn}$ methionine supplementation can reduce fetal loss in some mammalian populations.

To distinguish the mechanism(s) of how $\mathrm{Zn}$ might reduce the incidence of fetal loss, supplementation trials coupled with monitoring of daily health are needed. In particular, better characterization of markers of inflammation and environmental, nutritional and microbiological factors that may contribute to, or protect from, risk of fetal loss are necessary. Similarly, serum $\mathrm{Cu}$ concentrations in the three herds (herds 1, 3 and 4) with the highest rates of abortion were low, suggesting that low $\mathrm{Cu}$ concentrations may be associated with spontaneous abortion. Thus, the efficacy of $\mathrm{Cu}$ supplementation on prevention of spontaneous abortion should also be determined. The required sample size to avoid finding a treatment effect when one does not exist $(\alpha=0.05)$ and to identify correctly a treatment effect when treatment truly reduces the rate of abortion $(\beta=0.95)$ is approximately 800 per group if a reduction in the incidence of abortion from $10 \%$ to $5 \%$ is to be discerned (Fleiss, 1972).

In summary, low concentrations of $\mathrm{Zn}$ (serum or dietary) were associated in this study with an increased risk of fetal loss in four different environments. This study points to problems in methodology and approach for diagnosing nutrient status as a cause of fetal loss. Our data suggest that inflammation may be an important cause of fetal loss in California Holstein dairy cows. Whether a similar pattern of change in dietary and serum $\mathrm{Zn}$ or $\mathrm{Cu}$ concentrations may predict fetal loss in women needs further definition.

This study was supported by the US Department of Agriculture under the Animal Health Act of 1977, Public Law 95-113, a stipend from the Livestock Disease Research Laboratory, Zinpro Corporation, the California Milk Advisory Board, NIH HD-14388 and HD-01743. The authors thank M. S. Clegg, K. Andrews, M. Wilson and S. Edenson for helping to prepare samples for analysis, C. Jameson and C. Ozanian for help in collecting data and maintenance, DHI-Provo for providing the herd data, J. Genzoli for helping to coordinate the supplementation of the cattle, W. Johnson for statistical advice, and L. Denning and S. Denning for logistical support.

\section{References}

Anderson GB (1991) Fertilization, early development, and embryo transfer. In Reproduction in Domestic Animals (4th Edn) pp 279-313 Ed. PT Cupps. Academic Press, San Diego

Anderson ML, Blanchard PC, Barr BC and Hoffman RL (1991) A survey of causes of bovine abortion occurring in the San Joaquin Valley, California Journal of Veterinary Diagnostic Investigation 2 283-287

Apgar J (1992) Zinc and reproduction: an update joumal of Nutritional Biochemistry 3 266-278

Association of Official Analytical Chemists (1980) Official Methods of Analysis of the Association of Official Analytical Chemists (13th Edn) pp 125-161 Ed. W Horowitz. Association of Official Analytical Chemists, Washington DC
Austen J, Mahomed K, James D and Hathaway M (1989) Maternal leucocyte zinc levels and spontaneous first trimester abortion Early Human Development 20 $77-78$

Barber EF and Cousins RJ (1988) Interleukin-1-stimulated induction of ceruloplasmin synthesis in normal and copper-deficient rats Journal of Nutrition 118 375-381

Bell LT, Branstrator M, Roux C and Hurley LS (1975) Chromosomal abnormalities in maternal and fetal tissues of magnesium- or zinc-deficient rats Teratology 12 221-226

Breskin MW, Worthington-Roberts BS, Knopp RH, Brown Z, Plovie B, Mottot NK and Mills JL (1983) First trimester serum zinc concentrations in human pregnancy American Journal of Clinical Nutrition 38 943-953

Cherry FF, Sandstead HH, Rojas P, Johnson LK, Batson HK and Wang XB (1989) Adolescent pregnancy: associations among body weight, zinc nutriture, and pregnancy outcome American Journal of Clinical Nutrition 50 945-954

Clegg MS, Keen CL, Lonnerdal B and Hurley LS (1981) Influence of ashing techniques on the analysis of trace elements in animal tissue. I. Wet ashing Biological Trace Element Research 3 107-115

Cox DR and Oakes D (1984) Analysis of Survival Data. Chapman and Hall, London

Dinarello CA (1989) Interleukin-I and its biologically related cytokines Advances in Immunology 44 153-205

Dixon WJ, Sampson P and Mundle P (1990) One- and two-way analysis of variance with data screening. In BMDP Statistical Software Manual Vol. I pp 189-212 Ed. WJ Dixon. University of California Press, Berkeley

Egan AR (1972) Reproductive responses to supplemental zinc and manganese in grazing Dorset Horn ewes Australian Journal of Experimental Agriculture and Animal Husbandry 12 131-135

Engelman L (1990) Stepwise logistic regression. In BMDP Statistical Software Manual Vol. 2 pp 1013-1046 Ed. WJ Dixon. University of California Press, Berkeley

Fleiss JL (1972) Statistical Methods for Rates and Proportion p 176. John Wiley and Sons, New York

Garvey JS (1991) Antibodies to metallothionein Methods in Enzymology 205 141-174

Ghosh A, Fong LYY, Wan CW, Liang ST, Woo JSK and Wong V (1985) Zinc is not a cause for abortion, congenital abnormality and small-for-gestational age infant in Chinese women British Joumal of Obstetrics and Gynaecology 92 886-891

Giri SN, Emau P, Cullor JS, Stabenfeldt GH, Bruss ML, BonDurant RH and Osburn BI (1990) Effects of endotoxin infusion on circulating levels of eicosanoids, progesterone, cortisol, glucose and lactic acid and abortion in pregnant cows Veferinary Microbiology 21 211-231

Giri SN, Stabenfeldt GH, Moseley TA, Graham TW, Bruss ML, BonDurant RH, Cullor IS and Osburn BI (1991) Role of eicosanoids in abortion and its prevention by treatment with flunixin meglumine in cows during their first trimester of pregnancy journal of Veterinary Medicine A $\mathbf{3 8}$ 445-459

Goldhaber MK and Fireman BH (1991) The life table revisited: spontaneous abortion rates in three Kaiser Permanente cohorts Epidemiology 2 33-39

Graham TW (1991) Trace element deficiencies in cattle Veterinary Clinics of North America Food Animal Practice 7 153-215

Grider A, Bailey LB and Cousins RJ (1990) Erythrocyte metallothionein as an index of zinc status in humans Proceedings of the National Academy of Sciences USA 86 1259-1262

Hambidge KM, Neldner KH and Walravens PA (1975) Zinc, acrodermatitis enteropathica and congenital malformations Lancet i 577-578

Hertz-Picciotto I, Swan SH, Neutra RR and Samuels SJ (1989) Spontaneous abortions in relation to consumption of tap water: an application of methods from survival analysis to a pregnancy follow-up study American Journal of Epidemiology 130 79-93

Higashi A, Tajiri A, Matsukura M and Matsuda I (1988) A prospective survey of serial maternal serum zinc levels and pregnancy outcome Journal of Pediatric Gastroenterology and Nutrition 7 430-433

Hinks LJ, Ogilvy-Stuart A, Hambidge KM and Walker V (1989) Maternal zinc and selenium status in pregnancies with a neural tube defect or elevated plasma alpha-fetoprotein British Journal of Obstetrics and Gynaecology 96 6I-66

Hopkins A (1990) Survival analysis with covariates. In BMDP Statistical Software Manual Vol. 2 pp 769-806 Ed. WJ Dixon. University of California Press, Berkeley 
Hopkins A and Hornung R (1985) New 2L features with illustrative examples BMDP Technical Report No. 80 pp 1-21. University of California Press Berkeley

Hunt IF, Murphy NJ, Cleaver AE, Faraji B, Swendseid ME, Coulson AH, Clark VA, Browdy BL, Cabalum MT and Smith JC (1984) Zinc supplementation during pregnancy: effects on selected blood constituents and on progress and outcome of pregnancy in low-income teenagers of Mexican descent American Journal of Clinical Nutrition 40 508-521

Hunt IF, Murphy NJ, Cleaver AE, Faraji B, Swendseid ME, Browdy BL, Coulson AH, Clark VA, Settlage RH and Smith JC (1985) Zinc supplementation during pregnancy in low-income teenagers of Mexican descent: effects on selected blood constituents and on progress and outcome of pregnancy American Journal of Clinical Nutrition 42 815-828

Hurley LS and Shrader RE (1975) Abnormal development of preimplantation rat eggs after three days of maternal zinc deficiency Nature 254 427 -429

James WH (1983) Birth order, maternal age and spontaneous abortion Early Human Development 8 179-180

Jameson S (1976) Effects of zinc deficiency in human reproduction Acta Medica Scandinavica Supplementum 593 1-89

Kahn HA and Sempos CT (1989) Statistical Methods in Epidemiology pp 72-83. Oxford University Press, New York

Kalbfleisch JD and Prentice RL (1980) The Statistical Analysis of Failure Time Data. John Wiley and Sons, New York

Keen CL and Feldman BF (1987) Measurement of zinc and copper in plasma: potential negative effects of anticoagulant choice on analyzed values Agri-Practice 8 4-5

Keen CL and Gershwin ME (1990) Zinc deficiency and immune function Annual Review of Nutrition 10 415-431

Keen CL and Hurley LS (1989) Zinc and reproduction: effects of deficiency on foetal and postnatal development. In Zinc in Human Biology pp 183-220 Ed. CF Mills. Springer-Verlag, Berlin

Keen CL, Taubeneck MW, Daston GP, Rogers IM and Gershwin ME (1993a) Primary and secondary zinc deficiency as factors underlying abnormal CNS development Annals of the New York Academy of Science 678 37-47

Keen CL, Golub MS, Lonnerdal B, Olin KL, Graham TW, Uriu-Hare J and Gershwin ME (1993b) Influence of dietary zinc intake on pregnancy outcome in Rhesus monkeys Pediatric Research 33 141-174

Kirkbride CA (1992a) Etiologic agents detected in a 10-year study of bovine abortions and stillbirths Journal of Veterinary Diagnostic Investigation 4 175-180

Kirkbride CA (1992b) Viral agents and associated lesions detected in a 10-year study of bovine abortions and stillbirth Joumal of Veterinary Diagnostic Investigation 4 374-379

Kirkbride CA (1993) Bacterial agents detected in a 10-year study of bovine abortions and stillbirths Journal of Veterinary Diagnostic Investigation 5 64-68

Kline J, Stein Z, Susser M and Warburton D (1985) Fever during pregnancy and spontaneous abortion American Journal of Epidemiology $121832-842$

Kline J, Stein Z and Susser M (1989) Conception to Birth: Epidemiology of Prenatal Development. Oxford University Press, New York

Knudtson WU and Kirkbride CA (1992) Fungi associated with bovine abortion in the northern plains states (USA) Journal of Veterinary Diagnostic Investigation 4 181-185

Lazebnik N, Kuhnert BR, Kuhnert PM and Thompson KL (1988) Zinc status, pregnancy complications, and labor abnormalities American Journal of Obstetrics and Gynecology 158 161-166

Lohuis JACM, Verheijden JHM, Burvenich C and van Miert ASJPAM (1988a) Pathophysiological effects of endotoxins in ruminants 1 . Changes in body temperature and reticulo-rumen motility, and the effect of repeated administration Veterinary Quarterly 10 109-116

Lohuis JACM, Verheijden JHM, Burvenich C and van Miert ASJPAM (1988b) Pathophysiological effects of endotoxins in ruminants 2. Metabolic aspects Veterinary Quarterly 10 117-125
McMichael AJ, Dreosti IE and Gibson GT (1982) Maternal zinc status and pregnancy outcome: a prospective study. In Clinical Applications of Recent Advances in Zinc Metabolism pp 53-66 Eds AS Prasad, IE Dreosti, BS Hetzel. Alan R. Liss, Inc., New York

Mahomed K, James DK, Golding J and McCabe R (1989) Zinc supplementation during pregnancy: a double blind randomised controlled trial British Medical Journal $299826-830$

Masters DG and Fels HE (1980) Effect of zinc supplementation on the reproductive performance of grazing Merino ewes Biological Trace Element Research 2 281-290

Masters DG and Moir RJ (1983) Effect of zinc deficiency on the pregnant ewe and developing foetus British Journal of Nutrition 49 365-372

Meadows NJ, Ruse W, Smith MF, Day J, Keeling PWN, Scopes JW and Thompson RPH (1981) Zinc and small babies Lancet ii 1135-1137

Mukherjee MD, Sandstead HH, Ratnaparkhi MV, Johnson LK, Milne DB and Stelling HP (1984) Maternal zinc, iron, folic acid, and protein nutriture and outcome of human pregnancy American Journal of Clinical Nutrition $\mathbf{4 0}$ 496-507

National Research Council (US) Subcommittee on Dairy Cattle Nutrition (1988) Nutrient Requirements of Dairy Cattle (6th Edn). National Academy Press, Washington DC

Naylor AF and Warburton D (1979) Sequential analysis of spontaneous abortion: II. Collaborative study data show that gravidity determines a very substantial rise in risk Fertility and Sterility 31 282-286

Peters IM, Wiley LM, Zidenberg-Cherr S and Keen CL (1991) Influence of short-term maternal zinc deficiency on the in vitro development of preimplantation mouse embryos Proceedings of the Society for Experimental Biology and Medicine 198 561-568

Sato M, Mehra RK and Bremner I (1984) Measurement of plasma metallothionein in the assessment of the zinc status of zinc-deficient and stressed rats Journal of Nutrition $\mathbf{1 1 4} 1683-1689$

Shuster DE, Kehrli ME and Stevens MG (1993) Cytokine production during endotoxin-induced mastitis in lactating dairy cows American Joumal of Veterinary Research 54 80-85

Simmer K, Lort-Phillips L, James C and Thompson RPH (1990) A double-blind trial of zinc supplementation in pregnancy European Journal of Clinical Nutrition 45 139-144

Sookne D and Forsythe A (1990) t tests. In BMDP Statistical Software Manual Vol. 1 pp 145-162 Ed. W J Dixon. University of California Press, Berkeley

Stabel JR and Spears JW (1989) Effect of copper on immune function and disease resistance Advances in Experimental Medicine and Biology 258 243-252

Thomas EA, Bailey LB, Kauwell GA, Lee D-Y and Cousins RJ (1992) Erythrocyte metallothionein response to dietary zinc in humans Journal of Nutrition $\mathbf{1 2 2}$ 2408-2414

Thurmond MC and Picanso JP (1990) A surveillance system for bovine abortion Preventive Veterinary Medicine 8 41-53

Thurmond MC, Picanso JP and Jameson CM (1990a) Considerations for use of descriptive epidemiology to investigate fetal loss in dairy cows Joumal of the American Veterinary Medical Association 197 1305-1312

Thurmond MC, Picanso JP and Hietala S (1990b) Prospective serology and analysis in diagnosis of dairy cow abortion Journal of Veterinary Diagnostic Investigation 2 274-282

Wells JL, James DK, Luxton R and Pennock CA (1987) Maternal leucocyte zinc deficiency at start of third trimester as a predictor of fetal growth retardation British Medical Journal 294 1054-1056 (correction on page 1258)

Wilcox AJ, Weinberg CR, O'Connor JF, Baird DD, Schlatterer JP, Canfield RE, Armstrong EG and Nisula BC (1988) Incidence of early loss of pregnancy New England Journal of Medicine 319 189-194

Winge DR, Gray WR, Zelazowski A and Garvey JS (1986) Sequence and antigenicity of calf metallothionein 11 Archives of Biochemistry and Biophysics $245254-262$ 